\title{
Isolepis tenella, a New Combination in Cyperaceae
}

\author{
A. Muthama Muasya \\ East African Herbarium, National Museums of Kenya, P.O. Box 45166, Nairobi 00100, \\ Kenya; and Laboratory of Plant Systematics, Institute of Botany \& Microbiology, \\ K.U. Leuven, Kasteelpark Arenberg 31, B-3001 Leuven, Belgium. \\ muthamamuasya@yahoo.com
}

David A. Simpson

Royal Botanic Gardens, Kew, Richmond, Surrey, TW9 3AB, United Kingdom.

D.Simpson@rbgkew.org.uk

\author{
Erik Smets \\ Laboratory of Plant Systematics, Institute of Botany \& Microbiology, K.U. Leuven, \\ Kasteelpark Arenberg 31, B-3001 Leuven, Belgium. \\ Erik.Smets@bio.kuleuven.ac.be
}

Abstract. Since the publication of a monograph on Isolepis (Cyperaceae) in 2002, further data on the genus have been collected, necessitating additional nomenclatural change. Isolepis is a predominantly southern hemisphere genus with high species diversity in South Africa and Australia. A new combination is made here: Isolepis tenella (L.f.) Muasya \& D. A. Simpson, transferring an aberrant annual previously named Cyperus tenellus.

Key words: Cyperaceae, Cyperus tenellus, Isolepis tenella.

Recent systematic studies in the genus Isolepis $\mathrm{R}$. Brown in Cyperaceae have led to the publication of a monograph and phylogeny reconstructions at supraand infrageneric levels (Muasya \& Simpson, 2002; Muasya et al., 1998, 2000, 2001, 2002). Isolepis comprises 70 species, which are most commonly found in the temperate southern hemisphere, especially in South Africa and Australia. Isolepis is sister to Ficinia Schrader and, together with three other genera (Desmoschoenus J. D. Hooker, Hellmuthia Steudel, and Scirpoides Scheuchzer ex Séguier), it forms a clade sister to Cyperus L. s.l. The Isolepis and Cyperus s.l. clades are placed in tribe Cypereae, diagnosed by presence of a Cyperus-type of embryo (Goetghebeur, 1998). Isolepis is distinguished from Cyperus on the basis of spikelet morphology, having terete spikelets with spirally arranged glumes versus flattened spikelets with a distichous glume arrangement. However, flattened spikelets and semi-distichous glumes are observed in Isolepis (e.g., I. venustula Kunth), thus blurring generic boundaries.
Also, typical Cyperus-like spikelets are observed in Ficinia, but the latter genus is diagnosed by the presence of a hypogynous disk.

A phylogenetic study of Cyperus s.l. (Muasya et al., 2002), utilizing plastid ( $r b c \mathrm{~L}, r p s 16$ intron, $t r n \mathrm{~L}$ intron, and $t r n \mathrm{~L}-\mathrm{F}$ intergenic spacer) sequence data resolved Cyperus tenellus L.f. embedded within the IsolepisFicinia clade and sister to Isolepis cernua (Vahl) Roemer \& Schultes. This position has been confirmed by an expanded analysis of Cyperaceae incorporating $r b c \mathrm{~L}$ sequence data (Simpson et al., in press). We are convinced that this taxon belongs to Isolepis and make a new combination below.

Isolepis tenella (L.f.) Muasya \& D. A. Simpson, comb. nov. Basionym: Cyperus tenellus L.f., Suppl. Pl.: 103 (1782). TYPE: South Africa, Linnean Herbarium no 71/2 (lectotype, designated here, LINN).

Isolepis tenella is a tufted annual to ca. $10 \mathrm{~cm}$ tall, that has a pseudolateral inflorescence, spikelets that are flattened with a distichous glume arrangement, and papillose nutlets. Isolepis tenella shares its flattened spikelet morphology with I. venustula Kunth and has glume and nutlet features that are similar to I. cernua (Vahl) Roemer \& Schultes. We interpret the presence of flattened spikelets in I. tenella to be a character derived from a terete spikelet morphology and consider the taxon to belong to the I. cernua-I. venustula clade, members of which have overall morphological and habitat similarity and are phylogenetically most closely related. 
A similar interpretation of spikelet morphology was used to transfer Isolepis leucoloma (Nees) Archer from Cyperus (Archer, 1998). Both species occur in the Western Cape flora of South Africa and were the only annual species of Cyperus in that flora. Given that Isolepis is the only genus of Cyperaceae that has evolved an annual life form in the Cape flora, the placement of these species within Cyperus was inappropriate. We classify Isolepis tenella and $I$. leucoloma in Isolepis subg. Isolepis sect. Cernuae (C. B. Clarke) Muasya (sensu Muasya \& Simpson, 2002). The three species in this section with flattened spikelets can be separated on gross morphological characters.

Key to the Species in Isolepis sect. Cernuae With Flattened Spikelets

1a. Rhizomes horizontal; glumes 1.7-2.5 mm, nutlets 1.0-1.4 mm long; restricted to sandy beaches in South Africa............... . venustula

1b. Rhizomes absent or ascending; glumes 1.1$1.7 \mathrm{~mm}$, nutlets $0.6-1.0 \mathrm{~mm}$ long; widespread in inland seasonally wet areas, in South Africa and Australia .................... 2

2a. Plants taller, to $10 \mathrm{~cm}$; glumes $1.5-1.7 \mathrm{~mm}$ long, pale green; nutlets $0.8-1.0 \mathrm{~mm}$ long; in South Africa and Australia. ....... I. tenella

2b. Plants minute, to $3 \mathrm{~cm}$; glumes $1.1-1.2 \mathrm{~mm}$ long, dark brown with white margins; nutlets to $0.6 \mathrm{~mm}$ long; in South Africa . . . I. leucoloma

While carrying out this work, it became apparent that no type had been designated for Isolepis tenella. In the protologue given in Species Plantarum Supplementarum (Linnaeus f., 1782), there is no reference to any source of material. However, in the Linnean Herbarium (LINN), there is a single specimen annotated as "tenella." This material is instantly recognizable as I. tenella. No material corresponding to this species that may have been seen by the younger Linnaeus has been found elsewhere, and it is quite possible that the protologue was based on this specimen. Therefore, we designate Linnean Herbarium no $71 / 2$ as the lectotype.

Acknowledgments. AMM is a visiting postdoctoral fellow of the Fund for Scientific Research-Flanders (FWO-Vlaanderen, Belgium) and of the K. U. Leuven (grant F/02/052).

\section{Literature Cited}

Archer, C. 1998. A new combination in Isolepis. Bothalia 28: $41-42$.

Goetghebeur, P. 1998. Cyperaceae. P. 168 in K. Kubitzki (editor), The Families and Genera of Vascular Plants 4. Springer, Berlin.

Linnaeus, Carl von, filius. 1782. Supplementum Plantarum Systematis Vegetabilium Editionis Decimae Tertiae, Generum Plantarum Editiones Sextae, et Specierum Plantarum Editionis Secundae. Editum a Carolo a Linné. Brunsvigae [Braunschweig]: 103.

Muasya, A. M. \& D. A. Simpson. 2002. A monograph of the genus Isolepis R. Br. (Cyperaceae). Kew Bull 57: 257-362. $\longrightarrow$, M. W. Chase \& A. Culham. 1998. An assessment of the suprageneric phylogeny in Cyperaceae using $r b c \mathrm{~L}$ DNA sequences. Pl. Syst. Evol. 211: 257-271. - - , $\&$ \& 2000. Phylogenetic relationships within the heterogeneous Scirpus s. lat. (Cyperaceae) inferred from $r b c \mathrm{~L}$ and $\operatorname{trn} \mathrm{L}-\mathrm{F}$ sequence data. Pp. 610-614 in K. L. Wilson \& D. A. Morrison (editors), Monocots: Systematics and Evolution. CSIRO, Melbourne.

-,- - 2001. A phylogeny of Isolepis (Cyperaceae) inferred using plastid $r b c \mathrm{~L}$ and $t r n \mathrm{~L}-$ F sequence data. Syst. Bot. 26: 342-353.

——— \& 2002. Phylogenetic relationships in Cyperus s.l. (Cyperaceae) inferred from plastid DNA sequence data. Bot. J. Linn. Soc. 138: 145-153.

Simpson, D. A., A. M. Muasya, M. Alves, J. J. Bruhl, S. Dhooge, M. W. Chase, C. A. Furness, K. Ghamkhar, P. Goetghebeur, T. R. Hodkinson, A. D. Marchant, R. Nieuborg, A. A. Reznicek, E. H. Roalson, E. Smets, J. R. Starr, W. W. Thomas, K. L. Wilson \& X. Zhang. In press. Phylogeny of Cyperaceae based on DNA sequence data-A new $r b c \mathrm{~L}$ analysis. In: J. T. Columbus, E. A. Friar, J. M. Porter, L. M. Prince \& M. G. Simpson (editors), Monocots: Comparative Biology and Evolution, 2 vols. Rancho Santa Ana Botanic Garden, Claremont, California. 